\title{
"Merecedoras das páginas da história": memórias e representações da vida e da morte femininas (Belém, séculos XIX e XX)*
}

\author{
Franciane Gama Lacerda**
}

\section{Resumo}

O texto discute os muitos significados dados à morte de duas mulheres dos grupos menos abastados em Belém do Pará. Tais mulheres foram assassinadas em momentos distintos $e$ tiveram a história de suas vidas e de suas mortes evocada por literatos, estudiosos da região e na imprensa paraense, como um exemplo a ser seguido por outras mulheres, revelando ideais de fidelidade, casamento, de família, entre outros. Se ainda hoje a força dessas histórias vem à tona com significados diversos, no passado não foi diferente sugerindo os muitos sentidos dados a suas vidas e a suas mortes.

Palavras-chave: Memórias, Morte, Mulheres, Pará, Séculos XIX e XX.

\footnotetext{
* Recebido para publicação em 27 de outubro de 2010, aceito em 07 de junho de 2011.

** Faculdade de História, Universidade Federal do Pará. francianeglacerda@gmail.com
}

cadernos pagu (38), janeiro-junho de 2012:395-423. 
"Deserving the Pages of History": the Memory and Representation of Women's Life and Death (Belém, 19 ${ }^{\text {th }}$ and $20^{\text {th }}$ centuries)

\begin{abstract}
This paper discusses the many meanings given to the deaths of two poor women in Belém do Pará (Brazil). These women were killed at different times and had the story of their lives and deaths evoked by writers, scholars and the media, as an example to be followed by other women, revealing ideals of fidelity, marriage, family. If in modern days the strength of these stories still emerges with different meanings, the past was not different, indicating the many meanings given to their lives and deaths.
\end{abstract}

Key Words: Memories, Death, Women, Pará, Nineteenth and Twentieth Centuries. 
Bois-Guilbert, answered the Jewess, thou knowest not the heart of a woman, or hast only conversed with those who are lost to her best feelings. I tell thee, proud Templar, that not in thy fiercest battles hast thou displayed more of thy vaunted courage than has been shown by woman when called upon to suffer by affection or duty Ivanhoe, Sir Walter Scott

Da pena de Sir Walter Scott surgem as palavras fortes ditas pela judia Rebeca ao templário Bois-Guilbert, numa plena evocação à força das mulheres, que seriam capazes de resistir às mais fortes dores e provações quando movidas pelo amor e pelo dever. De fato, para muitos homens e mulheres sofrer por afeição e dever seria um apanágio feminino que deveria ser apreendido desde tenra idade. Por essa visão, no Brasil do século XIX, a Igreja e a família seriam elos importantes para a formação do caráter das mulheres, que, tal qual as representações de Sir Walter Scott, poderiam sofrer os maiores martírios em nome de sua fé e do amor a sua família. Assim, se as mulheres eram frágeis seria justamente a formação moral $e$ cristã que permitiria a estas não se desviarem do caminho das virtudes, mesmo que fosse necessária a perda da própria vida. Com tais atitudes, as mulheres, escrevia o literato Joaquim Norberto em 1862, seriam "merecedoras das páginas da história" (Silva, 1862:4).

Algumas das evidências das questões ora discutidas foram apresentadas na medida em que pesquisava o processo migratório de cearenses que deslocaram-se para o estado do Pará entre 1889 e 1916 (Lacerda, 2010). Desse modo, ao manusear a documentação disponível em arquivos do Estado do Pará e do Ceará, deparei-me com um número expressivo de histórias envolvendo mulheres que de variadas formas buscavam a sua sobrevivência na região amazônica. Viajando muitas vezes sós, ou como responsáveis por extensas familias, declarando-se solteiras, 
casadas ou viúvas, quando da seca no Ceará, em 1889, por exemplo, percebemos muitas delas requerendo junto ao governo cearense passagens para partirem em busca de uma vida melhor na província do Pará ou do Amazonas (id., 2003). O olhar acerca desses registros em que a iniciativa do processo migratório era feita pelas mulheres e não pelos homens, como convencionou-se em parte da historiografia ${ }^{1}$, levou-me, mesmo que este não tenha sido o foco da pesquisa, a não perder de vista as variadas experiências ${ }^{2}$ sociais das mulheres migrantes em terras paraenses.

Assim, buscando compreender os significados que migrantes cearenses davam a esta experiência, deparei-me no jornal Folha do Norte, muito lido no Pará em finais do século XIX e primeiras décadas do século $\mathrm{XX}$, com a história de duas mulheres que viveram em Belém em momentos diversos. Tratava-se, de Severa Romana, maranhense assassinada em 1900, e Maria Bárbara, paraense, assassinada no início do século XIX, cuja história era novamente trazida à tona em texto publicado em 1915. Ao lado disso, as notícias veiculadas na imprensa traziam quase que diariamente histórias de mulheres dos grupos menos abastados

${ }^{1}$ Um exemplo disso é o trabalho de Arthur Cezar Ferreira Reis, O seringal e o seringueiro, que embora importante para compreensão da Amazônia apresenta ideias como a da quase ausência de mulheres ou dos "tipos sociais" que viviam nos seringais e foram incorporadas na historiografia amazônica como explicações clássicas para a história da borracha na região (Reis, [1953] 1997). Com perspectiva diversa temos o trabalho de Cristina Wolff, Mulheres da Floresta: uma história: Alto Juruá, Acre (1890-1945), em que ganha destaque no espaço da floresta a participação das mulheres. Wolff foge das abordagens tradicionais, dos homens sozinhos em meio à floresta na coleta do látex, e traz à tona variadas experiências vivenciadas por mulheres migrantes, índias ou caboclas da região. Para a autora, a ausência das mulheres nos seringais, se justifica também a partir de um certo "sentido militante (...) que costuma ignorar quase por completo a experiência social das mulheres" (Wolff, 1999:15).

2 O conceito "experiência" será utilizado ao longo do texto a partir de Edward P. Thompson ao enfatizar que homens e mulheres "experimentam situações $e$ relações produtivas determinadas como necessidades $e$ interesses $e$ como antagonismos, e em seguida 'tratam' essa experiência em sua consciência e sua cultura" (Thompson, 1981:182). 
marcadas por violências, que iam desde o dono de um hotel que ficava com a mala de uma hóspede quando esta não tinha como pagar pelo tempo de hospedagem, até furtos, espancamentos e assassinatos. ${ }^{3}$ Esse cotidiano da cidade de Belém que crescia na virada do século XIX, em decorrência dos negócios do látex e de incentivo a agricultura levou-me a uma reflexão acerca de como a sociedade desse contexto compreendia a violência sofrida pelas mulheres e como a imprensa representava tais eventos.

Tal preocupação acabou gerando a escolha das histórias de Severa Romana e Maria Bárbara. De fato, mesmo que acontecida em tempos diversos a história de uma levava ao encontro da outra, pela ideia construída a respeito delas na imprensa cujo elo de ligação era o martírio sofrido por estas em nome do "dever conjugal" (Folha do Norte, 5/07/1900:1). A busca pela história dessas mulheres ${ }^{4}$ levou-me a um emaranhado de informações em que a memória de suas mortes fora evocada como forma de se apontar padrões comportamentais a serem seguidos ou não pelas mulheres. Tal perspectiva remete ao pensamento de Le Goff, ao compreender a memória também como um instrumento de poder

${ }^{3}$ Folha do Norte. Belém 10 de julho de 1900:2; 14 de julho de 1900:2; 15 de julho de 1900:2; 16 de julho de 1900:2; 21 de julho de 1900:2; 15 de agosto de 1900:2.

${ }^{4}$ Embora referindo-me às mulheres, compreendo a experiência vivida por estas construídas a partir das relações de gênero como sugere Joan Scott em "História da mulheres". A autora referindo-se ao trabalho nas ciências sociais enfatiza que o uso da categoria gênero, "presume uma correlação direta entre as categorias sociais masculino e feminino $e$ as identidades de sujeito dos homens $e$ das mulheres, $e$ atribui sua variação a outras características sociais estabelecidas como classe ou raça". Assim, para a autora o gênero "amplia o foco da história das mulheres" pluralizando a representação das mulheres na medida em que se considera também as "diferenças que a raça, a classe, a etnia e a sexualidade produziram nas experiências históricas das mulheres" (Scott, 1992:88-89). Sobre a categoria gênero ver também Matos, Soler, 1997. Para uma leitura acerca da variadas abordagens da produção historiográfica acerca da história das mulheres no Brasil ver: Del Priore, 1998:217-235. Também sobre a constituição de um campo de estudos acerca da história das mulheres e os usos da categoria gênero e suas relações com a trajetória do feminismo no Brasil ver: Correa, 2001. 
sugerindo uma luta "pela dominação da recordação e da tradição" (Le Goff, 1990:476).

Assim, este texto discute a construção de uma memória acerca da vida e da morte de duas mulheres que viveram em Belém do Pará entre o início e o fim do século XIX, que foram assassinadas e em momentos diversos tiveram a história de suas vidas evocadas por literatos, estudiosos da região e na imprensa paraense, tornando-se então, tomando aqui a ideia de Le Goff, mulheres-memória. ${ }^{5}$ Se ainda hoje a força dessas histórias vem à tona com significados diversos, no passado não foi diferente sugerindo os muitos sentidos dados à vida e à morte de Severa Romana e de Maria Bárbara.

1. Morte e vida de Severa Romana

Em julho de 1900, muitos moradores de Belém acompanharam pela imprensa, a morte da lavadeira Severa Romana, assassinada à navalhadas, em sua própria casa, às vésperas do nascimento de seu primeiro filho. $\mathrm{O}$ impacto desse assassinato pode ser percebido pela cobertura feita pela imprensa, que noticiou quase que diariamente o fato ao longo de mais de um mês. Desde as primeiras notícias do crime, a imprensa considera Severa Romana como "vítima de seu dever conjugal" (Folha do Norte, 5/07/1900:1). O crime, conforme ficou registrado nos jornais e, igualmente, na tradição oral, teria como motivação o fato de o soldado Antônio Ferreira dos Santos ter se apaixonado por Severa Romana, de quem era hóspede, tentando seduzi-la. Como esta se recusava a relacionar-se com ele, depois de muitos assédios, na noite de 2 de julho de 1900, o cabo Santos a assassinou, apresentado-se em seguida ao comandante da unidade a que pertencia (Folha do Norte, 4/07/1900:2).

5 Tomo aqui a ideia de Jacques Le Goff sobre os chamados "homensmemórias", que são "prestigiosos, e úteis", por guardarem uma memória importante para a identidade do grupo (Le Goff, 1990:429-449). Ironicamente, Severa e Bárbara, passam a ter essa função a partir de suas mortes. 
$\mathrm{Na}$ ocasião, e mesmo muitos anos depois, a imprensa $e$ literatos que escreveram sobre o crime não deixaram de se referir à violação do lar de Pedro de Oliveira, companheiro de Severa Romana, representada nas tentativas de sedução que esta possivelmente sofria em tal espaço. Desse modo a casa, símbolo material do lar, aparece como extensão de seus próprios moradores, cabendo também aos seus moradores a constituição de valores para uma família disciplinada e consequentemente civilizada. Assim, comparando o "lar" a um verdadeiro "sacrário", com sua áurea de sagrado, um articulista da Folha do Norte, argumentava que diante do martírio de Severa Romana a mulher paraense mostrava "ter nascido para o lar, sacrário das afeições santas, da felicidade" (Folha do Norte, 8/07/1900:1).

É justamente na luta por manter este lar, que Severa passa a ser inicialmente considerada como santa, na medida em que se associa sua pobreza, vista claramente em seu domicílio, às suas virtudes. Sendo o "habitat", conforme lembra Certeau, também a "confissão involuntária de uma maneira mais íntima de viver e de sonhar" (Certeau, 1996:204), a casa em que ela vivia chamada inclusive no jornal de "barraca", dada à sua precariedade, aparece com um elemento importante na representação de sua imagem de santidade (Folha do Norte, 4/08/1900:1). Apesar disso, observando mais atentamente o domicilio dela, veremos que se tratava de um grupo bastante singular, se tomarmos como referência os padrões homogêneos da família burguesa, ou da família patriarcal, extensa, comandada por um homem. ${ }^{6}$

${ }^{6}$ Para uma abordagem teórico-metodológica da temática da família ver: Laslett, 1972. Embora Laslett investigue a realidade inglesa, suas proposições são utilizadas no Brasil. É o caso do trabalho de Samara, 1989, cuja leitura demonstra a utilização no Brasil da chamada demografia-histórica, com adaptações metodológicas, para a investigação da história da família em São Paulo no século XIX. Para uma visão das abordagens sobre família ver: Anderson, 1984, que permite uma compreensão geral de estudos sobre a história da família no Ocidente a partir do século XVI. Ainda acerca da família no Brasil ver os seguintes trabalhos: Almeida, 1982; Almeida, 1987; Silva, 2001; Samara, 2002, Cancela, 2011. 
De fato, no domicilio de Severa viviam além dela e do marido, Joana Gadelha, viúva, cearense, parteira de 50 anos de idade e o cabo Antônio dos Santos, que havia chegado do Ceará. O grupo composto por migrantes havia sido formado cerca de um ano antes aproximadamente, pois no seu depoimento a parteira Joana afirmava que "conhecia a vítima há um ano e meio $e$ durante esse tempo não viu um só ato praticado por ela que desabonasse a sua conduta". Ainda sobre o grupo, Antônio Ferreira, o assassino, quando interrogado, disse, referindo-se a Severa que a "conhecia desde fevereiro" (Folha do Norte, 4/08/1900:1). A forma como o domicílio de Severa Romana estava constituído indica que na cidade, os moradores pobres buscavam alternativas de moradia e consequentemente de sobrevivência.

Tais arranjos domiciliares eram uma prática habitual em Belém. De fato, com as exportações de látex e com projetos de colonização agrícola, no início do século $\mathrm{XX}$ a cidade crescia, atraindo muita gente, sem, entretanto, ter condições de moradia para todos. Segundo Cancela, em Belém, "o preço alto dos aluguéis, a expansão demográfica $e$ a dificuldade de moradia contribuíram para o aumento no número das habitações coletivas". Tais habitações podiam ser formadas por "quartos em estalagens, vacarias e sobrados, cortiços e hotéis", cujos principais moradores eram migrantes nacionais e estrangeiros (Cancela, 2011:125). É comum encontrarmos na Folha do Norte notícias de queixas prestadas à Chefatura de Polícia por moradores desses domicílios. São denúncias de furtos de objetos pessoais e de dinheiro, ou brigas que tinham como acusados moradores da casa da vítima. Os conflitos não seriam de se admirar, uma vez que se tratavam de domicílios formados por pessoas que se conheciam há pouco tempo, mas que por força das circunstâncias de aluguéis caros, acabavam por viver em uma mesma casa. Isso é o que alegava José Maria, ao registrar uma queixa de furto em sua casa: "não podendo pagar sozinho, alugou os quartos a diversos colegas" (Folha do Norte, 2/08/1900:2). 
Nesses espaços, importantes também eram os vizinhos, companheiros nas horas de infortúnio, mas que também observavam e emitiam opiniões sobre o comportamento uns dos outros. O vizinho de Severa Romana, buscando demonstrar o comportamento dela, afirmou que "nunca ouviu dizer nada contra a sua honra, tendo ela (...) boa conduta". Se os depoimentos de pessoas próximas à vítima permitem entrever a organização de seu domicílio, o depoimento do assassino sugere muito de seu cotidiano de trabalho, indicando a participação dela no provimento da casa. De fato, Antônio conhece Severa a partir do marido desta, que a indica para cuidar de suas roupas, visto que ela "lavava e engomava bem" (Folha do Norte, 4/07/1900:2).

O ofício de lavadeira era muito comum em Belém, gerido pelas mulheres, tinha papel fundamental na economia familiar. $\mathrm{O}$ dia de trabalho das lavadeiras começava "muito cedo", por volta das 5h30 da manhã, conforme descrevia em 1900 a Folha do Norte, e uma vez "engolido o café", tais mulheres saíam a percorrer as ruas com o "seu xarão cheio de vestidos e casacos, recolhendo-se à noite" (Folha do Norte, 20/07/1900:2). O trabalho de percorrer as ruas tanto para a entrega das roupas limpas como para o recebimento de outras sujas, talvez explique as muitas caminhadas de Severa Romana pela cidade, usadas no depoimento de seu assassino como um atenuante de seus atos, na medida em que Severa Romana, não parecia ser uma mulher muito reclusa ao seu lar. ${ }^{7} \mathrm{De}$ fato, considerando-se que não se tinha água encanada em casa, e que muitas mulheres lavavam roupas em igarapés, além do hábito de colocar roupas para coarar ao sol, o que muitas vezes se fazia nas ruas, não era de se estranhar que Severa Romana circulasse tanto pelo bairro do Umarizal onde morava.

É provável que nem sempre Severa recebesse dinheiro por este trabalho sendo paga também com produtos de que precisava. Antônio Ferreira afirma que numa ocasião Severa pedira ao

7 Sobre trabalho feminino no espaço urbano ver: Dias, 1984. 
marido que dissesse a Antônio que lhe "comprasse alguns pães para ela comer". Além da lavagem de roupas a rotina diária de Severa incluía a compra e preparação de alimentos consumidos na casa, algumas vezes até por outros soldados do batalhão, como informou o Cabo Antônio em seu depoimento. (Folha do Norte, 4/08/1900:1). Assim, visando construir a imagem de uma mulher pouco confiável, Antônio afirmava que, no dia do crime, Severa, "passeou pelo Umarizal e outros pontos". Ao lado disso, alegava ainda que "não havia um soldado ou paisana que ela não conhecesse" (Folha do Norte, 4/07/1900:2). Por essa perspectiva, o espaço público, parecia ser inadequado à boa conduta feminina. Contraditoriamente, a faina cotidiana de Severa apresentada pela imprensa, sugere que, gerindo a economia doméstica, engendrando a sobrevivência familiar, as mulheres pobres mantinham uma estreita ligação entre a casa e a rua. Assim, a rua, conforme assevera Michelle Perrot, não era "apenas um corredor de circulação, mas também um meio de vida" (Perrot, 1992:221).

Entre os dias 3 de julho e 13 de agosto de 1900 o jornal paraense Folha do Norte, deu destaque ao caso, construindo desde estes primeiros momentos uma imagem de Severa como uma verdadeira heroína que, apesar de sua pobreza, resistira aos assédios do soldado Antonio lutando para não "manchar" a sua união conjugal. Tais elementos não eram necessariamente novos, quando se tratava de exaltar as virtudes de uma mulher dos grupos menos abastados. Modelar nesse sentido é o livro Brasileiras Célebres, de Joaquim Norberto de Souza Silva, publicado em 1862, no Rio de Janeiro, pela livraria Garnier. Tal edição que trazia à lume uma "galeria de senhoras brasileiras" consideradas celebridades pelos seus "talentos e virtudes", conforme advertia o editor ainda em 1861, era destinada "ao povo e adaptada às escolas", e igualmente "aos mimos e aos prêmios que se oferecem à senhoras" (Silva, 1862:V-VI).

$\mathrm{O}$ autor, membro do Instituto Histórico e Geográfico Brasileiro, lembrava logo nas primeiras páginas do texto, que o Brasil, "Nação de ontem", já tinha seus "heróis que enumeraram 
gloriosas batalhas", já tinha inclusive "edifícios monumentais dignos das primeiras capitais de reinos seculares", e em breve teria seus "monumentos históricos". O Brasil, já era, portanto, na visão de Joaquim Norberto, uma nação que em pleno esplendor do império tinha homens e mulheres dignos de registro por suas "ações gloriosas". É certo que as mulheres, personagens centrais do livro de Joaquim Norberto, eram segundo ele, ainda "insignificantes enquanto seu número". A justificativa para isso, de acordo com o autor, era decorrente dos "poucos anos de nossa existência nacional" se comparadas com as "nações do velho mundo". Por isso mesmo, tratava-se de verdadeira "justiça" afirmava o autor, utilizando-se do pensamento do Cônego Januário da Cunha, levar ao "conhecimento do mundo" as histórias das "senhoras que as praticaram", visto que estas deveriam ocupar o "mesmo distinto lugar" dos "varões afamados por letras, armas e virtudes" (Silva, 1862:1-2).

Assim, Joaquim Norberto justificava o seu empenho editorial lembrando que "já era por demais sentida a falta de um livro" que apresentasse as "patriarcas" brasileiras que por suas virtudes e heroísmos eram "merecedoras das páginas da história". Nesse sentido, corroborando com seu pensamento anterior, o autor acreditava que a história da nação que se firmava naqueles meados do século XIX, teria também sido feita por algumas mulheres, não por todas, mas por aquelas que, conforme "as crônicas da pátria" ou "tradições nacionais" haviam dado provas de "amor à pátria (...), exemplos de virtudes, atos de piedade $e$ mostras de ilustração" (Silva, 1862:4).

Nesse sentido, as mulheres que entravam no rol das heroínas formadoras da nação eram aquelas que abraçadas à fé cristã foram capazes de atos de bravura. Não sem razão, no primeiro capítulo do livro intitulado "Amor e fé", quando Joaquim Norberto se propõe a falar de três mulheres descendentes de índios ou escravos negros, ele asseverava que ao "cristianismo" o Brasil devia o fato de essas mulheres terem sido "arrancadas às brenhas" e vindas "à luz da civilização". Assim, para o autor era a 
fé trazida pela Coroa portuguesa e acolhida por mulheres como Paraguaçu ou Catarina Alves, Damiana da Cunha ${ }^{8}$ e Maria Bárbara que as moverá a "ações magnânimas" e "feitos de valor". É nesse cenário que merece uma página, mesmo que breve, a história de Maria Barbara, "pobre e modesta mameluca" que vivera no Pará no século XVIII, a quem o autor chamou de a "mártir do amor conjugal" (Silva, 1862:54-62).

Pode-se dizer que na forma de serem representadas, as histórias de Severa Romana e Maria Bárbara se entrelaçam. De fato, Joaquim Norberto quando descreve as virtudes da paraense Maria Bárbara, história que nos deteremos mais a seguir, faz questão de dizer que esta tinha uma vida "pura" $e$ "vivia satisfeita" resignada a sua pobreza $e$ "morreria ignorada do mundo" se sua vida não tivesse se convertido "n'uma tragédia horrivel" (Silva, 1862:64). Assim, a imagem de Severa Romana foi constituindo-se sob estas mesmas bases na imprensa paraense, quase quarenta anos depois da publicação de Joaquim Norberto.

Em 1900, entretanto, nem todos concordavam com louvores que a imprensa fazia às virtudes de Severa. Em uma das primeiras notícias produzidas sobre o crime, um possivel leitor da Folha do Norte perguntava: "Louvor para quê? Acaso de louvor carece aquele que cumpriu unicamente o seu dever?" E continuando, afirmava ainda "mal iria a sociedade se a cada mulher que guardasse a fidelidade de sua missão se fosse bater palmas". Tais comentários sugerem muito bem o que se esperava das virtudes femininas. Mas, esse pensamento parecia destoar do de muitos paraenses, outros comentários do tal leitor devem ser melhor considerados. Trata-se da afirmação de que a "onda de incenso" ao ato de Severa dava a supor "o que é uma sórdida descabida, que nas classes de que ela fazia parte são raros por isso louváveis os atos de mero dever da natureza" (Folha do Norte, 8/07/1900:1).

Assim, dentro de um modelo burguês de família, os homens $e$ mulheres pobres, em muitas circunstâncias, pareciam fugir

8 Sobre Damiana da Cunha, ver: Karasch, 1981. 
completamente ao que era entendido como um grupo disciplinado e civilizado. Sendo Severa Romana das camadas populares muitas vezes pensadas como "classes perigosas" - sua atitude diante da morte e de sua honra pode ter causado estranheza. Talvez isto possa ter corroborado ainda mais para a construção dos louvores ao seu "martírio". Neste caso, as proposições desse leitor da Folha do Norte não eram tão descabidas assim.

A fala do leitor da Folha do Norte não deixa de ser significativa por trazer à tona a convicção de que as virtudes femininas também estavam ligadas ao grupo social a que se pertencia. Nesse sentido, o preocupado leitor paraense, se aproxima de Joaquim Norberto e de suas "brasileiras célebres". Ora, conforme se pode observar nas páginas deste, as mulheres pobres, negras e índias consideradas de "raça desgraçada" tinham atitudes nobres quando movidas pela fé cristã por elas professada. Por isso para Joaquim Norberto, era uma "estranha contrariedade" a constatação de que "mulheres criadas no seio do catolicismo" caíssem "pelos degraus do vício" (Silva, 1862:54). Desse modo, era como se em certa medida, indo contra tudo que sua situação social lhe impusera, Severa tivesse se mantido fiel às verdadeiras virtudes femininas. Por essa perspectiva, utilizandonos das palavras do próprio Joaquim Norberto, o ato de Severa não deixava de ser também uma "estranha contrariedade".

Assim, a violência, a pobreza, o trabalho, a própria gravidez de Severa Romana e a sua possível luta contra seu agressor para não manchar a honra de seu marido, tal qual fizera anos antes Maria Barbara, serão atitudes evocadas na imprensa e ao mesmo

9 Ver: Bresciani, 1982; Rago. Luzia Maragareth. 1985; Chalhoub, 1986; Chalhoub, 1990, 2-22. Sidney Chalhoub, analisando epidemias no Rio de Janeiro afirma que "as classes pobres não passaram a ser vistas como classes perigosas apenas porque poderiam oferecer problemas para a organização do trabalho e a manutenção da ordem pública. Os pobres ofereciam também perigo de contágio". Para combater tal problem as autoridades acreditavam na "repressão à ociosidade" e nos cuidados com a "educação dos menores" (Chalhoub, 1996, 29). 
tempo servirão para comover a população de Belém, que de diversas formas se envolveu em homenagens à vítima. Segundo a Folha do Norte mais de 3000 pessoas foram ao cemitério em 13 de agosto de 1900, o que nos sugere uma grande comoção social, quando da inauguração do túmulo de Severa construído com fundos angariados pelo Corpo de Bombeiros de Belém. Nessa ocasião, Higino Amanajás, orador oficial da comissão, teria proferido um discurso que comovera os presentes que se solidarizavam como o marido de Severa Romana que chorara "copiosamente durante todo o ato" (Folha do Norte, 13/08/1900:2).

Não seria à toa que Higino Amanajás, educador e político paraense, na época diretor do Diário Oficial, participava dessa homenagem à Severa. Tendo sua trajetória profissional ligada à formação moral e cívica de crianças e jovens Amanajás havia publicado em 1898 as Noções de educação cívica: para uso das escolas primárias do Estado do Pará, livro adotado em escolas paraenses. Nesse livro Amanajás deixaria entrever os valores que deveriam nortear a vida em sociedade da recente república brasileira. Acreditava ele que "a educação cívica e moral" das crianças e jovens concorreria "para a felicidade e o progresso" do país (Amanajás, 1898:VII). De fato, como aponta Martha Abreu, no final do século XIX as autoridades preocupavam-se com a "formação de trabalhadores $e$ cidadãos sadios moral $e$ sexualmente", uma vez que o cuidado com a "educação das gerações futuras" levaria a ordem e ao progresso da nação que se estava construindo com a República (Abreu, 1999:290).

Nesse sentido, pode-se dizer, que a morte de Severa Romana, tomada como um exemplo a ser seguido pela juventude, representava exatamente um comportamento austero $e$ disciplinado, fundamental para a construção de uma sociedade com ordem e progresso, conforme acreditava Higino Amanajás. Assim, relendo o livro publicado por Amanajás em 1898, é possível imaginar um pouco da tônica de seu discurso diante do túmulo de Severa Romana, uma vez que ao lado das noções de amor à pátria apareciam referências ao "deveres" como 
fundamentais para a construção da nação brasileira. Nesta perspectiva, mesmo que nem soubesse disso, diante da recusa às seduções de seu assassino, Severa Romana parecia ter se enquadrado perfeitamente neste ideário, o que certamente era visto como sinal de honra por Amanajás. Assim, o autor afirmava que "como mãe de família, como mestra ou educadora, a mulher teria campo vasto para exercitar os seus deveres de patriota." Neste caso, o assassinato de Severa Romana, parecia ser exemplar, uma vez que para Amanajás tais deveres deveriam ser cumpridos mesmo que para tal fosse necessária a morte (Amanajás, 1898:110).

Corroborando com este pensamento, ao final de seu livro, fica registrado, um "Hino a Pátria" que conclamava as crianças $e$ a juventude a lutarem por seus ideais. Tal hino bem pode ter sido evocado por Amanajás diante do túmulo de Severa Romana:

Ah! Se teus nobres brios

Alguém quiser manchar

Por ti, pátria querida

A vida quero dar (Amanajás, 1898:113).

Diante de tudo que representava a morte de Severa Romana em 1900, não era de estranhar-se que tal evento tivesse ficado marcado na memória de muitas pessoas que vivenciaram o fato ou que dele tiveram conhecimento pela tradição oral. Tal constatação vai ao encontro do pensamento de Le Goff, quando este autor lembra que a memória pela "propriedade de conservar certas informações" remete a um "conjunto de funções psíquicas" que permite a atualização de "impressões ou informações passadas" ou que se "representa como passadas" (Le Goff, 1990:423). De fato, notadamente nos dias próximos às comemorações dos finados, quando muitas pessoas dirigem-se ao cemitério de Santa Isabel em Belém, a memória do martírio e das virtudes de Severa Romana vez por outra vem à tona. 
Foi assim que em novembro de 1940, com o sugestivo título "Assassinada há quarenta anos, ainda hoje o povo zela pela sua sepultura. O povo crê obter graças e benefícios por intercessão dela", o jornal $O$ Estado do Pará trazia em sua primeira página a lembrança da morte de Severa, reforçando ainda a ideia de uma morte exemplar. Dizia o articulista, que "o tempo não influi em nada" visto que mesmo tanto depois do crime ainda havia uma veneração à Severa por seu "admirável exemplo" de "fidelidade matrimonial", que em 1940 parecia já ter consagrado Severa Romana, como uma santa popular (O Estado do Pará, 22/11/1940:15). Alguns anos depois, baseado nesse artigo de jornal, entre 1946 e 1947, era publicado pela editora Guajarina um folheto de "literatura de cordel" intitulado História completa de Severa Romana. Em tal folheto o poeta descrevia Severa e seu marido como "um venturoso casal". Além disso, faziam-se referências aos possíveis milagres realizados por Severa, $e$ igualmente aos pedidos feitos pelos devotos. Destacando-se o das moças, de verem "os proclamas na igreja" e dos noivos, que pediam para "as noivas sensatez como Severa", sugerindo mais uma vez o exemplo da "esposa fiel" (Anônimo, [1946/1947]:2-23) e um ideal de família, de mulher e de casamento. ${ }^{10}$

Os escritos acerca do caso de Severa Romana continuam nos anos que seguem. Temos como exemplo o texto Severa Romana, a mártir paraense, publicado em 1957 pelo literato paraense Jacques Flores. Alguns anos depois, a peça de teatro de Nazareno Tourinho (1970) intitulada Severa Romana, que contava a história do assassinato e o cotidiano da população de bairros populares Belém. Também em 1970, Ricardo Borges (1986:36970), publica o livro Vultos notáveis do Pará, elencando na galeria das "santas paraenses" Severa Romana e Maria Bárbara.

Ao lado desses registros escritos, a tradição oral também foi fundamental na construção de uma memória acerca de Severa Romana. Apesar disso, em pleno século XXI, fica evidente que

${ }^{10}$ Sobre a questão no Pará ver: Cancela, 2008. 
muitas pessoas mantêm um vínculo de devoção para com a figura de Severa Romana, sem, entretanto, conhecer as origens desse culto. "Eu só sei que dizem que ela é santa, minha irmã sempre que vem ao cemitério acende uma vela pra ela", afirmou uma das entrevistadas. Outra entrevistada que possivelmente teria lido o que foi escrito sobre Severa, conta tal história como se a tivesse vivido sem entretanto, ter idade para isso. ${ }^{11}$ Esses trâmites de construção da memória que a documentação pesquisada evidencia sugerem o que aponta Paul Ricoeur, ao refletir sobre as fragilidades da identidade, o fato de que a "memória não é somente rememoração pessoal e privada, mas igualmente comemoração, isto é partilhada". Desse modo, pode-se dizer que as muitas narrativas escritas $e$ orais sobre a morte $e$ a vida de Severa Romana indicam igualmente que "a nossa memória esta desde sempre associada à dos outros" (Ricouer, 2000).

Mas se hoje muitas pessoas nutrem uma devoção religiosa pela figura de Severa Romana, um elemento importante que os jornais não referiram, mas que é fundamental quando alguns entrevistados falam de Severa, é a sua beleza, numa estreita vinculação entre o belo e a santidade. Tal representação talvez tenha se constituído a partir da pintura no túmulo de Severa em que esta, sem que se saiba se corresponde exatamente à sua imagem, aparece como uma bela moça de olhos grandes, boca $e$ cabelos bem desenhados.

A beleza será também um elemento importante na composição da imagem da "mameluca" Maria Bárbara. De fato,

${ }^{11}$ Para este trabalho entrevistei sete pessoas com idade entre 40 e 80 anos. Foram feitas entrevistas curtas com o objetivo de entender alguns dos sentidos atribuídos por estes entrevistados à figura de Severa Romana. Os trechos aqui apresentados fazem parte deste conjunto de entrevistas. Ao longo do texto, estas pessoas são chamadas de entrevistados sem se identificar a fala de cada uma individualmente. Para a interpretação das entrevistas a leitura de autores como: Portelli, 1997; Thomson, 1997; Vilanova, 1997; foi fundamental, uma vez que estes trabalhos indicam que a construção análise e interpretação das memórias sobre o passado, a partir de documentos orais se fazem por uma multiplicidade de discursos entre o entrevistador $e$ os entrevistados. 
sem ter referências de como ela era, um articulista da Folha do Norte que rememora sua morte em 1915, constrói uma representação dela a partir das descrições de José Veríssimo. Embora José Veríssimo não tenha escrito sobre Maria Bárbara, em seu livro, Primeiras Páginas, publicado em Belém, em 1878, um capítulo era dedicado às "mamelucas" mistura do "sangue tupi com o português", com seus cabelos negros "lindas como sultanas, altivas como rainhas" (Veríssimo, 1878:121-125). Tal descrição, talvez se explique, conforme sugere Bezerra Neto, pelo fato de que Veríssimo, percebia "possíveis vantagens advindas do cruzamento das raças" para a "constituição de uma homogeneidade étnica a longo prazo, impedindo problemas raciais no Brasil". Nesse caso, "os colonos brancos portugueses assumiam a condição mais elevada" restando aos "índios e aos africanos a inferioridade racial" (Bezerra Neto, 2002:54-55). Nesse sentido, a "mameluca" de José Veríssimo parece se aproximar da "mameluca" de Joaquim Norberto, na medida em que beleza para o primeiro, e virtudes para o segundo, estavam associadas a estas mulheres a partir de suas ligações com os brancos e não por seus próprios atributos.

\section{Morte e vida de Maria Bárbara}

A história de Maria Bárbara, também evocada como memória várias vezes entre os paraenses, ganhou força pelo fato de esta mulher, sendo casada, ter resistido aos assédios de um soldado que desejava seduzi-la. De acordo com Ricardo Borges, no livro Vultos notáveis do Pará, Maria Bárbara teria sido assassinada em Belém, na confluência das atuais ruas Quintino Bocaiúva e Serzedelo Corrêa, no lugar conhecido no século XIX, como Fonte do Marco, "cujas águas lavadeiras utilizavam" (Borges, 1986:369). Seria justamente seu ato de resistência que a fez preferir "a morte à desonra" que a colocava no rol das brasileiras célebres, muito antes de Severa Romana ser assassinada. Tal ato foi visto por Joaquim Norberto como a prova de que a fidelidade conjugal, 
"uma das mais nobres características da mulher", era uma virtude que pertencia a "todas as classes, altas, medianas e baixas da sociedade". Esse argumento para Joaquim Norberto, se sustentava, no fato de que sendo pobre e descendente de "bárbaros selvagens, mas educada no catolicismo", Maria Bárbara tinha levado esse valor, até os extremos de sua própria morte (Silva, 1862:62-64).

Desse modo, Joaquim Norberto reforçava uma das principais ideias de seu livro, a de que os ensinamentos da fé trazidos pela coroa portuguesa desde os primórdios da colonização permitiram a muitas dessas mulheres ações como a de Maria Bárbara. Com essa perspectiva, o ato individual da não aceitação de Maria Bárbara da violência sofrida se perde e se valoriza mais o que a levou a fugir de seu algoz, no caso a sua fé. De fato, para Joaquim Norberto, sendo a "mameluca" descendente de índios e escravos negros, portanto, "bárbara", tal ato de bravura, só se explicava pela fé cristã que moldara e a encaminhara segundo o autor, para o seu "voluntário martírio". Com tais argumentos Maria Bárbara entrava para as "páginas da história" graças a educação que recebera, pois pela visão de Joaquim Norberto, de outro modo tal atitude de preferir a morte a "manchar a sua castidade" não existiria (Silva, 1862:64).

Seguindo a trilha deixada por Joaquim Norberto, ainda no segundo reinado, outros autores, buscando apontar o valor das ações que construíram a nação brasileira, com a propagação da fé católica, traziam também à tona as virtudes da mameluca Maria Bárbara, com as mesmas evidências de Brasileiras Célebres. São exemplos dessa perspectiva os livros Selecta Brasiliense ou Notícias, Descobertas, Observações, Factos e Curisosidades em relação aos Homens à História, e Cousas do Brasil de J.M.P de Vasconcelos, de 1868; o Lembranças e Curiosidades do valle do Amazonas do Cônego Francisco Bernardino de Souza de 1873; o Ano Biographico Brazileiro de Joaquim Manoel de Macedo de 1876. Embora, publicados em momentos diversos, percebe-se 
nesses textos uma grande aproximação com as representações de Joaquim Norberto sobre o assassinato de Maria Bárbara.

Assim, o Cônego Bernardino de Souza, que pretendia, como ele próprio enunciava, mostrar ao "público das demais províncias do império as curiosidades, as maravilhas" da Amazônia, também não esquece de Maria Bárbara. Nesse sentido, sua história parecia ir ao encontro das perspectivas que o próprio nome da obra já sugeria. Ao mesmo tempo, evocava-se mais uma vez a memória de Maria Bárbara, dessa vez, a partir dos versos do poeta amazonense Tenreiro Aranha (1769-1811), que teria sido contemporâneo de Maria Bárbara, e em um soneto representara a sua história como um exemplo ser seguido. Desse modo, evocando o trabalho do poeta Tenreiro Aranha o Cônego Bernardino lamentava a perda de muitos dos escritos do literato dando destaque a um soneto "escrito por ocasião do assassinato de uma mulher mameluca". Segundo o Cônego, o soneto era muito "popular no Pará" (Souza, 1873:5, 30). De fato, em todos os trabalhos escritos sobre Maria Bárbara, inclusive em Joaquim Norberto, tal soneto é reproduzido sugerindo um pouco da gênese da imagem construída ao longo do tempo acerca de Maria Bárbara, como aquela que preferiu à morte a manchar o amor conjugal:

Se acaso aqui topares caminhante,

Meu frio corpo já cadáver feito,

Leva piedoso (...)

esta nova ao esposo aflito, errante

(...) que teve uma consorte

Que, por honra da fé que lhe jurara,

À mancha conjugal prefere a morte.

Desse modo, ainda em 1915, o jornal paraense Folha do Norte trazia duas páginas dedicadas à história de Maria Bárbara, em artigo assassinado por Bento F. Tenreiro Aranha, neto do poeta amazonense que escrevera o soneto. $\mathrm{O}$ articulista ressentiase da ausência de documentos sobre a morte da mameluca $e$ lembrava que "a falta desses documentos não apagou, através de 
um século, a memória do terrível fato". Assim, na medida em que exaltava a memória de seu próprio avô, por ter descrito em soneto a triste história de Maria Bárbara, o autor mostrava aos leitores do periódico uma memória escrita e oral sobre a vida da mameluca (Folha do Norte, 27/05/1915:1)

Ao lado disso, inspirado em José Veríssimo, quando descreve a figura das mamelucas paraenses em Primeiras Páginas (1878), surgem no texto de Bento Aranha, conforme já evidenciamos a imagem forte e delicada das mamelucas (Folha do Norte. 27/05/1915:1). José Veríssimo na sua descrição das mamelucas, afirmava que estas viviam "entre as quatro melhores coisas da vida: perfumes e amores, doces e flores". A explicação para essa ideia vinha do próprio trabalho de coser e lavar roupas, de vender doces, e de fazer "cheiro" comumente desenvolvido por estas mulheres. A produção artesanal de "cheiros" para roupas, muito comum ainda hoje no Pará, era "uma indústria paraense e das mamelucas" afirmava José Veríssimo. Tal atividade consistia em "ralar em uma língua de pirarucu (...) cascas e raízes odorosas" e juntá-las a "pétalas de jasmins, de rosas, ramos de manjeronas e outras flores", que "metidos em pedaços de papel dobrados" e colocados em "pequenos balaios" eram vendidos pelas ruas (Veríssimo, 1878:127,128). Mas estas representações femininas no Pará, não ficaram restritas ao século XIX, um exemplo disso é tela pintada em 1947, por Antonieta Feio, intitulada "Mulata de cheiro/Vendedora de cheiro", que reproduz o "retrato de uma mulher mestiça" com um "cesto de palha repleto de raízes e plantas de cheiro forte" (Fernandes, 2008:144).

No início do século XIX, circulavam pelas ruas estreitas de Belém além de brancos portugueses, índios e escravos negros, as chamadas "mamelucas". Estas últimas mulheres teriam, de acordo com Antonio Ladislau Baena (1782-1850), impressionado o governador do Grão-Pará e Rio Negro, o Conde dos Arcos (18031806), que considerava "verdadeiramente singular o teor de trajar das mamelucas e mulheres pardas", a ponto de ser "digno de ser visto na corte". Tal impressão, ainda segundo Baena, levou o 
Conde dos Arcos a mandar "retratar" algumas dessas mulheres pelo pintor português Antonio Leonardo. O traje das mamelucas que tanto impressionaram o Conde dos Arcos era formado, por uma "uma saia de delgada caça, ou de seda nos dias de maior luxo, e de uma camisa". Pelo olhar atento de Baena, estas roupas eram "quase uma clara nuvem que ondeando inculca os moldes do corpo". Além disso, as mamelucas traziam consigo "cordões, colares, rosários, e bentinhos". Mas Baena não se esqueceu dos cabelos com madeixa "embebida em baunilha e outras plantas" perfumadas como os jasmins, o malmequer e as rosas (Baena, 1969 [1838]:258)

Se a "mameluca" que encantara o Conde dos Arcos era tempos depois descrita por José Veríssimo como "formosa", "morena", que encantava, com seu perfume de jasmim nos cabelos negros, que deixava quem passava por perto dela "meio embriagado" e com um corpo de "cintura grossa (...) sem ter a elegância da parisiense", mas a "lasciva das mulheres do oriente", sua aparente doçura e singeleza permitiam que Veríssimo a comparasse a um "beija-flor" que preferia a "rosa a um palácio". Apesar disso, segundo Veríssimo, a "mameluca" trazia em sua sina uma história trágica. Ela era destinada a "cair" em razão dos romances que sempre acabavam mal. Assim exclamava: "Coitadinha ela cai sem sentir" (Veríssimo, 1878:121-127). Maria Bárbara, que talvez tivesse tais encantos, ganhava as páginas da história justamente por não se deixar seduzir pelo seu assassino, mudando o rumo da trajetória a que pareciam ser destinadas as "mamelucas". Assim, na ausência de maiores informações sobre as origens e a vida da "mameluca", o articulista da Folha do Norte, acreditava ser Maria Bárbara "um tipo idêntico ao descrito por José Veríssimo (Folha do Norte, 27/05/1915:1).

Podemos associar essas imagens construídas acerca da "mameluca" paraense às imagens que se construíram nas artes $e$ na literatura acerca das "mulatas". Desse modo, conforme sugere Mariza Corrêa em relação à categoria "mulata", o que me parece ser possível aplicar à categoria "mameluca", e portando ao 
imaginário social acerca de Maria Barbara, no "âmbito das classificações de gênero ao encarnar de maneira tão explícita o desejo masculino branco, a mulata também revela a rejeição que essa encarnação esconde: a rejeição à negra preta" (Correa, 1996:50). De fato, tanto Veríssimo, como bem antes dele o Conde dos Arcos, não expressam seu encantamento pela beleza da mulher negra escrava, mas somente pela beleza da "mameluca", que representava, conforme pensava o primeiro, a mistura do índio com o português excluía-se assim, desse patamar de beleza os descendentes dos africanos.

Assim, tendo mudado o rumo de seu destino, mesmo que pela morte, no Pará, a força da história contada por Joaquim Norberto e por outros autores que o sucederam exaltando as virtudes de Maria Barbara, viria à tona outras vezes, sugerindo o alcance de Brasileiras Célebres. Em 1900, quando do assassinato de Severa Romana em Belém, a imagem de mulher virtuosa preconizada pela mameluca Maria Bárbara seria novamente evocada. Possivelmente, inspirados na leitura do texto de Joaquim Norberto, expressões como "mártir do amor conjugal", como fora chamada Maria Bárbara, ou "preferiu à morte à desonra", seriam uma constante na imprensa local. Aproximava-se assim, a história da morte dessas duas mulheres ocorridas na capital paraense, como uma forma de reforçar um ideal feminino. Chegou-se ao extremo, como foi o caso de uma leitora que teria escrito em julho de 1900, ao jornal Folha do Norte, de se indagar, comparando as circunstâncias da morte, qual das duas mulheres seria a mais virtuosa. Maria Bárbara ou Severa Romana? (Folha do Norte, 5/07/1900:1)

Sem dúvida, alguns elementos parecem unir as trajetórias de vida de Maria Bárbara e Severa Romana apesar de vivenciadas em tempos completamente diversos. Ambas eram das camadas populares, viviam pobremente do ofício de lavadeira, tinham como companheiros soldados e tiveram um final trágico sendo assassinadas. Apesar das semelhanças, na tradição paraense, talvez pelo próprio tempo em que se passa, ganhará mais força, 
chegando até os dias atuais, a história de Severa Romana. Assim, embora Severa Romana, tenha ficado mais conhecida entre os paraenses, tal história, em termos de uma narrativa escrita, notadamente construída pela imprensa, parece ter se inspirado nas páginas de Joaquim Norberto sobre a "mameluca" Maria Barbara.

Com o tempo, os significados em torno das figuras de Severa Romana e Maria Bárbara se modificaram. Embora cultuando Severa Romana, muitas pessoas não sabem de que forma ela morreu, não associando assim sua santidade às virtudes conjugais. ${ }^{12}$ Desse modo, encontramos hoje, no túmulo de Severa, no cemitério de Santa Izabel, um grande número de agradecimentos, ao lado daqueles, em que o devoto não revela publicamente o que lhe foi alcançado, o maior número deles é pela aprovação no vestibular.

E o que dizer de Maria Bárbara, que "não inspirou culto popular" (Borges, 1986:370), mas que inspirou como vimos, as próprias representações sobre Severa Romana? Embora ela conste no livro "Vultos notáveis do Pará" de Ricardo Borges, na galeria das "santas paraenses", a "mameluca" Maria Bárbara quase não é conhecida hoje, muito diferente do que fora no passado. Algumas possíveis razões podem explicar este desaparecimento de Maria Bárbara das crônicas da história: talvez, com a consolidação da nação, e com o próprio mito da igualdade racial, o Brasil já não necessitasse mais provar que teve heroínas mestiças. Por outro lado, a violência contra as mulheres passou a ser vista a partir de novos significados não cabendo apenas a exaltação à vítima, mas uma luta cotidiana por outras formas de relação social.

No que diz respeito à Severa Romana, a organização do acervo do Centro de Memória da Amazônia em Belém (onde se encontra guardado o processo sobre sua morte), ensejou um evento acerca de sua história em 2009. Tal evento trouxe a tona uma memória acerca desse passado, dando conta que se de um

${ }^{12}$ Sobre os "meios de produção e de transmissão da memória" ver: Valensi, 1994. 
lado história e memória estão em oposição conforme enfatiza Nora (1993:9) de outro lado, os historiadores diante de suas escolhas sobre o passado não deixam também de produzir memória. Ao lado disso, ainda segundo Nora, diante dessa ânsia contemporânea de "tudo guardar", cabe indagar "de que memória são indicadores" esses eventos? (id.ib.:16).

Neste sentido, as histórias de Severa Romana e Maria Bárbara revelam claramente, como, ao longo do tempo, as versões e compreensões de um mesmo acontecimento vão sendo tecidas por vários elementos, dando conta de que o passado, revisto pela memória, é extremamente dinâmico, ao mesmo tempo, que as narrativas da história e os "lugares da memória" (id.ib.:7-28), também se reinventam com novos significados.

\section{Referências bibliográficas}

ABreu, Marta. Meninas Perdidas. In: Del PRIORE, Mary (org.). História das crianças no Brasil. São Paulo, Contexto, pp.289-316.

ANDERSON, Michael. Elementos para a história da família ocidental 15001914. Lisboa, Editorial Querco, 1984.

BEZERRA NETO. Os males de nossa origem: o passado colonial através de José Verríssimo. In: BeZERRA Neto José Maia \& GuZMÁn, Décio de Alencar (orgs.). Terra matura: historiografia e história social na Amazônia. Belém, Paka-Tatu, 2002. pp.39-65.

BORGES, Ricardo. Vultos notáveis do Pará. Belém, CEJUP, 1986. [2a edição revista e aumentada]

BRESCIANI, Maria Stella. Londres e Paris no século XIX: o espetáculo da pobreza. São Paulo, Brasiliense, 1982.

CANCELA, Cristina. Destino cor de rosa, tensão e escolhas: os significados do casamento em uma capital amazônica (187-1920). Cadernos Pagu (30), Campinas-SP, Núcleo de Estudos de Gênero-Pagu/Unicamp, 2008, pp.301-328.

. Casamento e relações familiares na economia da borracha. Belém (1870-1920). Belém, Açaí, 2011. 
Certeau, Michel de; GiARD, Luce; MAYOl, Pierre. A invenção do cotidiano: 2. morar, cozinhar. Petrópolis/RJ, Vozes, 1996.

CHAlHOUB, Sidney. Trabalho, Lar e Botequim: o cotidiano dos trabalhadores pobres no Rio de Janeiro na belle-époque. São Paulo, Brasiliense, 1986.

. Casses Perigosas. Trabalhadores (6), Campinas, Secretaria Municipal de Cultura, Esportes e Turismo de Campinas, 1990, pp.2-22.

. A cidade febril: cortiços e epidemias na corte imperial. São Paulo, Companhia das Letras, 1996.

CORRÊA, Mariza. "Repensando a família patriarcal no Brasil". In: AlmEIDA, Maria \& KOFES, Suely (orgs.). Colcha de retalhos, estudos sobre a família no Brasil. São Paulo, Brasiliense, 1982, pp.13-38.

. Sobre a invenção da mulata. Cadernos Pagu (6-7), CampinasSP, Núcleo de Estudos de Gênero-Pagu/Unicamp, 1996, pp.35-50.

. Do feminismo aos estudos de gênero: uma experiência pessoal. Cadernos Pagu (16), Campinas-SP, Núcleo de Estudos de Gênero-Pagu/Unicamp, 2001, pp.13-30.

Del PRIORE, Mary. História das mulheres: as vozes do silêncio. In: FREITAS, Marcos Cezar (org.). Historiografia Brasileira em Perspectivas. São Paulo, Contexto, 1998, pp.217-235.

DIAS, Maria Odila Leite da Silva. Quotidiano e poder em São Paulo no século XIX. São Paulo, Brasiliense, 1984.

FERNANDES, Caroline. As cores do sol: visualidade regional $e$ representações da mulata na pintura brasileira. Revista Estudos Amazônicos (III/2), Belém, 2008, pp.141-163.

KARASCH, Mary. Damiana da Cunha: catechist and sertanista. In: NASH, Gary e SWEET, David (orgs.). Struggle and survival in colonial America. Berkeley, University of California Press, 1981, pp.102-20.

LACERDA, Franciane Gama. Migrantes cearenses no Pará: faces da sobrevivência (1889-1916). Belém, Açaí/PPHIST-UFPA/CMA-UFPA, 2010. 
- Requerendo passagem para si e sua família: mulheres migrantes no Pará da virada do século XIX. Projeto História (27), São Paulo, 2003, pp.305-320.

LASLETT, Peter. Household and family in past time. Cambridge, Cambridge University Press, 1972.

LE GOFF, Jacques. História e memória. Campinas, Editora da Unicamp, 1990.

MATOS, Maria Izilda S. de, SOLER, Maria Angélica (orgs.). Gênero em debate: trajetórias e perspectivas na historiografia contemporânea. São Paulo, EDUC, 1997.

MEZA, René Salinas. El ideario femenino chileno, entre la tradición y la modernidad (Siglos XVIII al XX). Estudos CEDHAL (8), São Paulo, 1993.

NORA, Pierre. Entre memória e história a problemática dos lugares. Projeto História (10), São Paulo, 1993, pp.7-28.

PERROT, Michelle. Os excluídos da história: operários, mulheres e prisioneiros. $2^{\mathrm{a}}$ edição. Rio de Janeiro, Paz e Terra, 1992.

PORTELLI, Alessandro. Tentando aprender um pouquinho. Algumas reflexões sobre ética na história oral. Projeto História (15), São Paulo, 1997, pp.13-49.

RAGo, Luzia Maragareth. Do Cabaré ao Lar: a utopia da cidade disciplinar (1890-1930). Rio de Janeiro, Paz e Terra, 1985.

REIS, Arthur César Ferreira. O seringal e o seringueiro [1953]. Manaus, EdUA/ Governo do Estado do Amazonas, 1997. [2a edição revista]

RICOUER, Paul. Identidade frágil: respeito pelo outro e identidade cultural. Disponível em: <http://www.uc.pt/fluc/lif/publicacoes/identidade fragil>

SAMARA, Eni de Mesquita (org.). A história da família no Brasil: bibliografia comentada. Versão revista e atualizada. São Paulo, CEDHAL/FFLCH/USP, 2002.

. Casamentos e papéis familiares em São Paulo no séc. XIX. Cadernos de Pesquisa, São Paulo, Fundação Carlos Chagas, 1981, pp.17-25. 
. Mistérios da 'fragilidade humana': o adultério feminino no Brasil, séculos XVIII e XIX. Revista Brasileira de História (15/29), São Paulo, 1995, pp.57-71.

- Patriarcalismo, Família e Poder na Sociedade Brasileira (Séculos XVI e XIX). Revista Brasileira de História (11/22), São Paulo, 1991, pp.7-33.

. Tendências atuais da história da família no Brasil" In: ALMEIDA, Ângela Mendes de (org.). Pensando a família no Brasil. Rio de Janeiro, Espaço e Tempo, 1987, pp.23-36.

. As mulheres, o poder e a família (São Paulo, Século XIX). São Paulo, Marco Zero/Secretaria do Estado da Cultura de São Paulo, 1989.

SCOTT, Joan. História das mulheres. In: BuRKE, Peter. A Escrita da história: novas perspectivas. São Paulo, Editora da Universidade de São Paulo, 1992, pp.63-95.

THOMPSON, Edward P. A Miséria da Teoria ou um planetário de erros uma crítica ao pensamento de Althusser. Rio de Janeiro, Zahar Editores, 1981.

THOMSON, Alistair. Recompondo a memória: questões sobre a relação entre História Oral e as memórias. Projeto História (15), São Paulo, 1997, pp.51-71.

TORRES-LONDOÑO, Fernando. A outra família: concubinato, Igreja e escândalo na colônia. São Paulo, Programa em História Social da Faculdade de Filosofia da USP/Edições Loyola, 1999.

VALENSI, Lucete. Fábulas da Memória: A batalha de Alcácer Quibir e o mito do sebastianismo. Rio de Janeiro, Nova Fronteira, 1994.

VILANOVA, Mercedes. A história presente e a história oral. Relações, balanço e perspectivas. Páginas de História (II/2), Belém, 1998, pp.1-15.

WolfF, Cristina Scheibe. Mulheres da Floresta: uma história: Alto Juruá, Acre (1890-1945). São Paulo, Hucitec, 1999. 


\section{Fontes impressas}

Folha do Norte. Belém, $2^{\circ}$ semestre de 1900.

Folha do Norte. Belém, 27 de maio de 1915.

O Estado do Pará. Belém 22 de novembro de 1940.

AmANAJÁs, Higino. Noções de educação cívica: para uso das escolas primárias do Estado do Pará. Belém, Typ. do Diário Oficial, 1898.

ANÔNIMO. História completa de Severa Romana. Belém, Edições do Museu da UFPA/Editora da UFPA, 1996.

FloRES, Jacques. Severa Romana, a mártir paraense. Rio de Janeiro, Conquista, 1955.

MACEDO, Joaquim Manoel de. Ano Biographico Brazileiro. Segundo volume. Rio de Janeiro, Typographia e Litographia do Imperial Instituto Artístico. 1876.

SILVA, Joaquim Norberto de Souza. Brasileiras Célebres. Rio de Janeiro, Livraria de B. L. Garnier, 1862.

SouzA, Cônego Francisco Bernardino de. Lembranças e Curiosidades do valle do Amazonas. Pará, Typ. do Futuro, 1873.

TouRINHO, Nazareno. Severa Romana. (Peça teatral em 3 atos). Belém, Governo do Estado do Pará, 1970.

VASCONCElOS, J.M.P de. Selecta Brasiliense ou Notícias, Descobertas, Observações, Factos e Curisosidades em relação aos Homens à História, e Cousas do Brasil. Rio de Janeiro, Typographia Universal de Laemmert, 1868.

Veríssimo, José. Primeiras Paginas: Viagens no sertão - Quadros Paraenses - Estudos. Belém, Typographia Guttemberg, 1878.

\section{Entrevistas}

Sra. Maria da Conceição

Sra. Maria de Souza

Sra. Dulce

Sra. Maria Rosilene

Sr. Francisco 